http://dx.doi.org/10.12775/szhf.2019.017

\author{
RadosŁaW KuliniaK \\ Uniwersytet WrocŁaWski, WrocŁaW, Polska \\ ORCID: 0000-0002-0090-6609 \\ E-MAIL: KORNIK90@POCZTA.ONET.PL
}

\title{
Czy Kazimierz Twardowski zajmował się filozofią Immanuela Kanta?
}

\section{Wstęp}

Próby zbudowania polskiej filozofii, dokonywane niemal od podstaw na przełomie XIX i XX wieku przez Kazimierza Twardowskiego, Henryka Struvego czy też Władysława Weryhę, są doskonale znane w obszarze polskiej literatury filozoficznej. Ich zasługi na tym polu były wielkie. Powołali do życia „Bibliotekę Filozoficzną”, „Przegląd Filozoficzny”, „Ruch Filozoficzny”, a także liczne towarzystwa filozoficzne, na czele z Polskim Towarzystwem Filozoficznym we Lwowie i Polskim Towarzystwem Psychologicznym w Warszawie. Swoje inspiracje czerpali z różnych źródeł. Czasem wystarczało własne doświadczenie. W wielu jednak momentach trzeba było sięgnąć do wiodących trendów myślenia w światowej filozofii. W tym czasie główną rolę odgrywały interpretacje filozofii Immanuela Kanta, które wyrastały z marburskich i fryburskich kręgów neokantowskich. We Lwowie i Warszawie dokładnie obserwowano ich rozwój i oddziaływanie. Bardzo szybko uznano, że kładąc podwaliny pod kształtowanie polskiej myśli filozoficznej, nie możemy 
opierać się na jednostronnych interpretacjach, pomijając przy tym inne, równie znaczące oddziaływania. Ani Twardowski, ani Struve i Weryho nigdy nie zaakceptowali dokonującego się w Marburgu przyjęcia Kantowskiej filozofii. Nie chcieli, aby polska recepcja tej myśli została zamknięta w marburskiej twierdzy ${ }^{1}$. Twardowski pisał i mówił o budowaniu polskiej filozofii, opartej na wypracowanej przez nas samych formie pracy, otwartej i sięgającej po sprawdzone w światowej filozofii osiągnięcia. Stał na straży pluralizmu filozoficznego. W swojej mowie inaugurującej działalność Polskiego Towarzystwa Filozoficznego we Lwowie 1904 roku przestrzegał:

W rozwoju polskiej filozofii bezpośredni wpływ Kanta zaznaczył się dotąd bardzo słabo. Bardzo silnym natomiast był jego wpływ pośredni. Najświetniejsze chwile rozwoju filozofii w Polsce pozostawały pod wpływem niemieckiej filozofii pokantowskiej, która wzięła od Kanta wiele pomysłów, ale nie przejęła się jego duchem krytycznym. I dlatego wyrodziła się w niesłychany dogmatyzm i upadła. A filozofia polska, wydawszy pod jej wpływem nie mniej świetne od niej blaski, również upadła. Tak w Niemczech płytki materializm, tak w Polsce zapewne nie tak płytki, ale może nieco powierzchownie pojęty pozytywizm był odpowiedzią i reakcją na poprzednie dogmatyczne bujanie w obłokach. Po wielkim bogactwie konstrukcji i spekulacji filozoficznych nastała u nas epoka zastoju; dowodem tego niski stan ogólnego wykształcenia filozoficznego i lekceważenie filozofii, które do niedawna u nas panowało. Tak smutny stan rzeczy nie byłby ustał, gdyby nasza myśl filozoficzna nie była się swego czasu ślepo oddana w niewolniczą służbę niemieckiej filozofii idealistycznej; byłby ją od tego uchronił duch Kanta, przemawiający z pism Jędrzeja Śniadeckiego, Jarońskiego i innych. Pomimo to nie wolno nam bez zastrzeżeń wołać: „wróćmy do Kanta". Wszak w haśle tym tkwi także wielkie niebezpieczeństwo. Dogmatyzmem byłoby twierdzić, że tylko Kant nas może czegoś nauczyć. Powinniśmy korzystać z nauki, którą nam daje nasza własna przeszłość filozoficzna. W niej przejawiają się kolejno różne wpływy obce. Wolff, francuscy sensualiści, idealiści niemieccy, pozytywizm - oto główne kierunki, którymi się przejmowali

${ }^{1}$ Por. uwagi na ten temat José Ortega y Gasset, Prólogo para alemanes, w: Obras completas (t. I-X, Madrid Fundación José Ortega y Gasset/Centro de Estudios Orteguianos: 2004-2010, t. I i II z 2004, t. III i IV z 2005, t. V i VI z 2006, t. VII z 2007, t. VIII z 2008, t. IX z 2009 i t. X z 2010), (t. VIII, 2008), 34. Szerzej o tym traktuje Dorota Leszczyna w José Ortega y Gasset. Dziedzictwo Kanta i neokantyzmu marburskiego, „Rozdział czwarty: José Ortega y Gasset a neokantyzmu marburski. 2.2. Pierwszy pobyt José Ortegi y Gasseta w Marburgu w roku akademickim 1906-1907" (Wrocław: Wydawnictwo Arboretum, 2011), 145-148. 
nasi filozofowie. Kierunki te działały po części po sobie, po części obok siebie, pochłaniając mniej lub więcej naszą własną myśl filozoficzną, wyciskając na niej piętno jednostronności. A tak być nie powinno. Warunki naszego rozwoju kulturalnego inne przeznaczają nam stanowisko także w rozwoju pracy filozoficznej. Nie powinniśmy ulegać jednostronnemu wpływowi tego lub owego kierunku, ani nawet tego lub owego narodu. Naszymi przewodnikami nie powinni być ani Anglicy, ani Francuzi, ani Niemcy wyłącznie, lecz wszyscy razem. Jesteśmy w tym szczęśliwym położeniu, że trzy przodujące w filozofii narody są nam $\mathrm{w}$ równej mierze obce, a przeto $\mathrm{w}$ równej mierze bliskie. I nie wolno nam dogmatycznie wierzyć, że ten lub ów z wymienionych narodów jest kat exochen narodem filozoficznym; musimy w pracy naszej opierać się na tym, co zdziałał każdy z nich. Nie wolno nam się dać opanować wpływom obcym, lecz musimy sami nad niemi zapanować i posiłkując się tym, co po tym sumiennym zbadaniu wyda się trwałym, samodzielnie brać udział w pracy wspólnej. Niechaj więc nikt $\mathrm{z}$ faktu, że rozpoczynamy pracę $\mathrm{w}$ rocznicę śmierci Kanta, nie wysnuwa wniosku, że chcemy kroczyć śladami filozofii niemieckiej; pamiętajmy raczej, że właśnie Kant jednoczył w sobie pierwiastki filozofii niemieckiej z pierwiastkami filozofii angielskiej i z niedocenionymi może dotąd najeżycie pierwiastkami filozofii francuskiej. Przetapiając samodzielnie te wpływy i łącząc je w wielkiej syntezie, wskazał drogę, którą i nam kroczyć trzeba. Oby praca nasza przyniosła, nie tylko nam samym korzyść, lecz także całemu społeczeństwu, oby była istotnym dorobkiem dla nauki, oto najgorętsze pragnienie, z którym działalność naszą rozpoczynamy².

Starał się zachęcić naszą społeczność filozoficzną do walki ze wszelkimi przejawami dogmatyzmu. Proponował, aby w trudnej pracy filozoficznej oprzeć się na dobrze rozpoznanym Kantowskim krytycyzmie. W swojej „Przemowie” zwracał uwagę, aby:

skupiać w sobie nie tylko wszystkich naszych pracowników na polu filozofii, lecz także wszystkie kierunki ich pracy, wszystkie kierunki, reprezentowane w ich poglądach. Polskie Towarzystwo Filozoficzne nie będzie służyło żadnemu kierunkowi filozoficznemu wyłącznie, albowiem pragnie objąć sobą wszystkie kierunki. Chce być wolnym od wszelkiej jednostronności, chce być jak najbardziej wszechstronnym. Jedynym dogmatem Towarzystwa będzie przekonanie, że dogmatyzm jest największym wrogiem wszelkiej pracy naukowej. Jak

${ }^{2}$ Zob. Kazimierz Twardowski, „Przemówienie inauguracyjne z okazji otwarcia Polskiego Towarzystwa Filozoficznego we Lwowie", Przegląd Filozoficzny Warszawski 7 (1904), 2: $241-243$. 
wszystkie promienie koła, chociaż z różnych wychodzą punktów obwodu, łączą i spotykają się w środku koła, tak też i my chcemy, aby wszystkie kierunki pracy i poglądów filozoficznych w naszym Towarzystwie ku jednemu zmierzały celowi, ku wyświetleniu prawdy. Drogą ku temu krytycyzm; on powinien nas uchronić od wszelkich uprzedzeń i formułek, z góry narzuconych lub dobrowolnie przyjętych. I dlatego niechaj to będzie szczęśliwą dla nas wróżbą, że rozpoczynamy pracę w setną rocznicę śmierci męża, który więcej, aniżeli ktokolwiek inny, przyczynił się do tego, że duch naukowego krytycyzmu przenikać zaczął badania filozoficzne. Immanuel Kant obrał sobie za hasło unicestwienie dogmatyzmu filozoficznego: praca jego życia starczy także nam za hasło i program. Zgodnie z jego żądaniem, będziemy zawsze usiłowali zdawać sobie sprawę z podstaw, na których się nasze twierdzenia i poglądy opierają; nie damy się łudzić pozorami naukowości, pomni na dialektykę pozorów Kanta; ale zgodnie z nim, nie będziemy też twierdzić, jakoby zimne, naukowe, logiczne operacje umysłu ludzkiego zadowoliły wszystkie jego potrzeby. Nie będziemy jednak wyznawać niewolniczo wszystkich poglądów Kanta; i do nich przyłożymy miarę, którą on nauczył filozofów władać. Niechaj więc pamięć Kanta będzie w nas żywą nie tylko w setną rocznicę jego śmierci, lecz niechaj nam zawsze w pracy towarzyszy, abyśmy się strzegli błędów, które on słusznie zwalczał, chociaż sam, człowiek ułomny, ustrzec ich się nie potrafił. Jeżeli w ogóle dla każdej pracy filozoficznej krytycyzm jest niezbędnym warunkiem powodzenia, trudno nie przyznać, że tym bardziej powinno się nim kierować w pracach Polskie Towarzystwo Filozoficzne ${ }^{3}$.

Twardowski dostrzegł wśród osiągnięć światowej filozofii niepowtarzalną szansę. Zauważył wraz ze swoimi współpracownikami konieczność dokonywania przekładów dzieł filozofów uznanych w świecie. Dość szybko rozpoznano, że na tym polu polska filozofia boryka się z ogromnym deficytem. Na początek zdecydowano o tym, aby dać polskiemu czytelnikowi do wglądu kilka dobrze przygotowanych polskich przekładów najważniejszych prac Kanta. Zaproszono do współpracy: Romualda Grzymałę-Piątkowskiego, Mścisława Wartenberga, Piotra Chmielowskiego, Feliksa Kierskiego i Benedykta Bornsteina. Namaszczono ich do wykonania zaszczytnego, lecz trudnego zadania. W niedługim czasie polska filozofia miała otrzymać co najmniej kilka ważnych przekładów dzieł Kanta i innych filozofów. Zamierzano przetłumaczyć prace Johna Locke’a, Davida Hume’a, George’a Berke-

${ }^{3}$ Tamże, 241-243. 
ley’a, Étienne’a Bonnot de Condillaca czy też Descartesa, Barucha Spinozy i Gottfrieda Wilhelma Leibniza. W przypadku Kanta działania translatorskie przekładają się na wysiłek całego pokolenia polskich filozofów, dla których wyznacznikiem stało się zmodyfikowane przez Struvego zawołanie neokantowskie o „powrót do Kanta”. Hasłem przewodnim dla polskich filozofów okazał się lansowany przez niego „powrót do filozofii w Polsce wraz z Kantem". Struve pisał o tym, jako pierwszy z naszych filozofów, w końcowym fragmencie swojej pracy Immanuel Kant a dziejowa doniosłość jego krytycy$z m u$. Zmodyfikował tam pierwotne neokantowskie zawołanie, wyraźnie zaznaczając:

Oto dalekie perspektywy na przyszłość, łączące się bezpośrednio z imieniem Kanta w sto lat po jego śmierci. W miejsce dotychczasowych nawoływań powrotu do Kanta, nadeszła pora do wygłoszenia hasła nowego: „Naprzód wraz z Kantem". Niech o tym nie zapomina młode pokolenie dojrzewających myślicieli, bo tu odsłania się nowe pole do rzetelnej pracy, do zasiewu i żniwa, w miejsce jałowego przeżuwania dobytków przeszłości! ${ }^{5}$

Hasło „powrotu do filozofii w Polsce wraz z Kantem” oznaczało przede wszystkim podjęcie prac o charakterze translatorsko-edytorskim. Twardowskiemu, Struvemu i Werysze chodziło o dobranie do wykonania tego zadania dobrze wykształconych filozofów i filologów ${ }^{6}$. Każda próba przekładu

${ }^{4}$ Zob. Henryk Struve, Wstęp krytycznym do filozofii (Warszawa 1898, wyd. II poprawione), 96. Czytamy tam: „Pierwszym, który, pojmując całą doniosłość krytycyzmu, nawoływał w nowszych czasach myślicieli do powrotu do Kanta (Zurück zu Kant!), był Ed. Zeller. Uczynił to w rozprawie: Die Bedeutung und Aufgabe der Erkenntnisstheorie 1862 (także w jego: Vorträge u. Abhandlungen, 2-te Sammlung 1877). W tym duchu działali również już przed trzydziestu przeszło laty: O. Liebmann (Kant u. die Epigonen 1865) i Alb. Lange (Geschichte des Materialismus 1866). Od tego czasu rozwija się coraz szerzej i głębiej nowokantyzm, będący najwydatniejszą cechą współczesnego ruchu na polu filozofii”.

${ }^{5}$ Zob. Henryk Struve, Immanuel Kant oraz dziejowa doniosłość jego krytycyzmu (Warszawa: Biblioteka Warszawska, t. 3, 1904), 36-37.

${ }^{6}$ Zob. Henryk Struve, „Od Redaktora »Biblioteki filozoficznej« (Napisana w Eltham pod Londynem w lutym 1904 r.)”, w: Immanuel Kant, Krytyka czystego rozumu, przełożył z oryginału Piotr Chmielowski, pod redakcją naukową Henryka Struvego z dodaniem „Wstępu” i „Objaśnień tłumacza” oraz „Skorowidzu nazwisk” i „Wyrazów naukowych” (Warszawa: Księgarnia E. Wende i Sp., Wydanie z zapomogi Kasy Pomocy dla osób pracujących na polu naukowym imienia Dra Józefa Mianowskiego, 1904), V-IX. 
miała być publicznie dyskutowana i szczegółowo komentowana na łamach czasopism filozoficznych. Dokładna analiza przetłumaczonego dzieła miała zaś sprzyjać jego upowszechnieniu. Liczyła się przy tym drobiazgowość toczących się polemik. Stała się ona normą i wspólnym obowiązkiem tłumacza, wydawcy i redakcji. Zresztą sam czytelnik wyczekiwał na to, aż w „Przeglądzie Filozoficznym” bądź w „Ruchu Filozoficznym ukaże się kolejna fascynująca na ten temat polemika.

Polskie prace translatorskie związano od samego początku z próbą stworzenia prospektu przekładów prac Kanta. Miały go utworzyć tłumaczenia: Prolegomenów do wszelkiej przyszłej metafizyki, która będzie mogła wystąpić w przyszłości jako nauka, Krytyki czystego rozumu, Krytyki praktycznego rozumu oraz Uzasadnienia metafizyki moralności. Te zamierzenia powiodły się nam znakomicie, a Twardowski, Struve i Weryho odegrali w tym przedsięwzięciu doniosłą rolę. Okazali się nie tylko cichymi inspiratorami i zwolennikami dokonywania przekładów oraz prowadzenia publicznych dyskusji na ich temat, lecz przede wszystkim doskonałymi popularyzatorami Kantowskiej filozofii. Kant był stale obecny w ich działalności.

Wśród rozlicznych dzieł Kanta, które postanowiono wówczas przetłumaczyć i przybliżyć polskiemu czytelnikowi, najważniejszym była oczywiście Krytyka czystego rozumu. Dokonanie jej pierwszego pełnego przekładu stało się nadrzędnym celem dla całego środowiska filozoficznego. Nie mogło jednak zabraknąć także innych tłumaczeń dzieł Kanta. Twardowskiemu najbardziej zależało na Kantowskich Prolegomenach. Świadczy o tym jego zaangażowanie oraz wsparcie obu ówczesnych prób ich przetłumaczenia. Zachowało się też dość szczęśliwie, choć nie w całości, a uczynione jego ręką Streszczenie z Kantowskich Prolegomenów. Tekst ten jest do dziś dnia bliżej nieznany w naszej literaturze filozoficznej. Zachował się wśród archiwaliów filozofa i jest przechowywany w Archiwum Połączonych Bibliotek WFiS UW, IFiS PAN i PTF, Archiwum Kazimierza Twardowskiego w Warszawie ${ }^{7}$. Nie był on dotąd publikowany. Został przez nas przepisany z maszynopisu i poprawiony w wielu miejscach wymagających bezpośredniej interwencji. Twar-

${ }^{7}$ Zob. Kazimierz Twardowski, „Kanta Prolegomena w streszczeniu”, mps 17 x $21 \mathrm{~cm}$, k. 14, po k. 16, k. A-H. luźne. 1. Tekst, k. 1-6. 2; „Anmerkung”, k. A-H. Nr spisu inw., P. 18,7 (Archiwum Połączonych Bibliotek WFiS UW, IFiS PAN i PTF, Archiwum Kazimierza Twardowskiego w Warszawie). 
dowski pracował nad nim w ścisłym związku z zajęciami dydaktycznymi prowadzonymi przez siebie we Lwowie. Po raz pierwszy przeprowadził lekturę i interpretację Prolegomenów w semestrze zimowym 1901/1902 w ramach seminarium filozoficznego wyższego ${ }^{8}$. Później do lektury tekstu Twardowski powrócił w roku akademickim 1904/1905 w semestrze letnim. Kolejny raz zajął się nim w roku akademickim 1912/1913 w semestrze zimowym i letnim. Za każdym razem korzystał z tekstu oryginalnego. Odnosił się do przekładu Grzymały-Piątkowskiego. Podejmował wreszcie własną próbę interpretacji i zasiadł do pulpitu, aby napisać Streszczenie do Kantowskiego dzieła. Chciał w ten sposób ułatwić sobie i studentowi pracę seminaryjną. Dalszym zaś celem było zmobilizowanie naszego środowiska filozoficznego do rewizji dokonanego już przekładu Prolegomenów. Twardowski marzył o nowym tłumaczeniu i jego wydaniu. Osiemnaście lat od przekładu Grzymały-Piątkowskiego znalazł się wreszcie inny tłumacz, a mianowicie Bornstein, z którym Twardowski podjął ścisłą współpracę. Samo Streszczenie Twardowskiego przybrało od samego początku formę krótkich, lecz treściwych uwag do wybranych fragmentów z tekstu Kanta. Szkoda jedynie, że nie zachowały się one w całości. Niemniej jednak i tak wydają się świadectwem rozległych zainteresowań Twardowskiego Kantowskimi koncepcjami. Podczas swoich wieloletnich zajęć prowadził również wnikliwą lekturę innych dzieł królewieckiego myśliciela. Już w roku akademickim 1903/1904 w ramach seminarium wyższego czytał Krytykę czystego rozumu. Proponował studentom lekturę i interpretację wybranych fragmentów z tego dzieła. Korzystał przy tym z oryginału niemieckiego tudzież za zgodą Chmielowskiego prezentował fragmenty tego tekstu w jego tłumaczeniu. Do lektury Krytyki czystego rozumu Twardowski powrócił w roku akademickim 1908/1909 w semestrze letnim. Później czytał ją ze studentami jeszcze raz, tj. w roku akademickim 1922/1923. Z kolei rok akademicki 1906/1907 przyniósł ze sobą lekturę i interpretację Kantowskiej Krytyki praktycznego rozumu w ramach podzielonego przez Twardowskiego

${ }^{8}$ Przegląd wykładów i innych zajęć z filozofii nowożytnej i współczesnej Twardowskiego tudzież innych filozofów czynimy na podstawie „Wykazów wykładów odbywać się mających w C. K. Uniwersytet imienia Cesarza Franciszka I. we Lwowie. Skład Uniwersytetu i program wykładów z lat 1876-1939”. Korzystamy też z publikacji: Ryszard Jadczak, Kazimierz Twardowski. Nota bibliograficzna, „Spis wykładów i seminariów Kazimierza Twardowskiego w Uniwersytecie Lwowskim” (Toruń: nakł. aut., 1991), 59-77. 
na grupę A i B seminarium filozoficznego wyższego. W semestrze letnim tegoż samego roku podjął się jeszcze zaznajomienia słuchaczy z Uzasadnieniem metafizyki moralności na podstawie przekładu Wartenberga. Twardowski chciał w ten sposób zachęcić lwowskiego kolegę do poprawienia swojego przekładu i do jego ponownego wydania. Sprawa jednak nie doczekała się realizacji, głównie z powodu kłopotów zdrowotnych tłumacza.

\section{Jak filozofia Immanuela Kanta trafiła na pulpit Kazimierza Twardowskiego?}

Charakterystyczne dla polskiej filozofii „pospolite ruszenia kantowskie” zaczęły się dość wcześnie. Jako pierwsze dzieło Kanta został przetłumaczony przez Józefa Władysława Bychowca Projekt wieczystego pokoju. Rozwaga filozoficzna ${ }^{9}$. Później doszło do publikacji kolejnego polskiego przekładu tego dzieła w tłumaczeniu Szymona Bielskiego ${ }^{10}$. Na przełomie XIX i XX wieku powstawały sukcesywnie następne rodzime edycje dzieł Kanta. W 1901 roku ukazało się tłumaczenie Prolegomenów autorstwa Grzymały-Piątkowskiego z „Przedmową” Struvego, a zaledwie trzy lata później została po raz pierwszy w całości przełożona na język polski ${ }^{11} \mathrm{i}$ wydana przez Chmielowskiego Kry-

${ }^{9} \mathrm{O}$ wątpliwościach w sprawie przekładu Bychowca pisał Mirosław Żelazny w artykule „Referat Piotra Chmielowskiego «Najdawniejsze wiadomości o E. Kancie w piśmiennictwie naszem»", Ruch Filozoficzny LXII (2005), 1: 58-60.

${ }^{10}$ Zob. Immanuel Kant, Projekt wieczystego pokoju. Rozwaga filozoficzna, tłum. Szymon Bielski (Królewiec, 1797).

${ }^{11}$ Należy nadmienić, że w Polsce ukazał się cząstkowy przekład (fragmenty) Krytyki czystego rozumu. Zob. Immanuel Kant, Krytyka czystego rozumu, fragmenty w przekładzie polskim tłum. Leon Grabowski, Ekonomia polityczna (Warszawa, 1864), „Oddz. 1, Teoria ekonomii politycznej”, 25-48. Ważną informację podaje Brożek, Piątkowski Romuald Grzymała, w: Polski słownik biograficzny (Kraków: Zakład Narodowy im. Ossolińskich - Wydawnictwo Polskiej Akademii Nauk 1981), t. 26, z. 1, 18-19 [hasło „Romuald Piątkowski Grzymała”. Wiemy stąd, że około 1900 roku Piątkowski dokonał przekładu Krytyki czystego rozumu, który gdzieś jeszcze pozostaje wciąż w rękopisie (najprawdopodobniej w „Magazynach Naukowych” w Orchard Lake w Stanie Michigan, USA). Obok poczynań Piątkowskiego wspomina się również o pomyśle „prof. Kreczmara z Warszawy”, który „legł jednak w gruzach” z powodu choroby tłumacza. 
tyka czystego rozumu ${ }^{12}$. Ostatnie rodzime wydanie dzieła Kanta ukazało się w momencie uzyskania przez nas niepodległości. Wówczas nakładem Księgarni Gebethnera i Wolffa w Warszawie opublikowano Prolegomena przetłumaczone po raz drugi przez Bornsteina ${ }^{13}$. Później nie ukazał się już żaden inny w tamtym czasie polski przekład dzieł Kanta ${ }^{14}$. Nie oznacza to, że pod rozbiorami oraz w wolnej Polsce przestano się nagle zajmować jego myślą. Była ona stale obecna. Oddziaływała na sposób uprawiania filozofii polskiej. Ważne były dwa jubileusze Kantowskie, tj. 100-lecie śmierci w 1904 roku i w 1924 roku 200-lecie urodzin. Można powiedzieć, że między nimi dokonała się jej asymilacja. Była ona związana, jak wspomnieliśmy, z próbami translatorskimi, właściwym odczytaniem założeń Kantowskiej filozofii, z jej recepcją, a także z powołaniem Polskiego Towarzystwa Filozoficznego we Lwowie. Znaleźli się u nas wówczas filozofowie, którzy interesowali się Kantem i docenili starania Hansa Vaihingera z 1897 roku, który zakładał wówczas światowe czasopismo „Kant-Studien”. Ta grupa „polskich zapaleńców kantowskich” była zainteresowana nie tylko współpracą z redakcją „Kant-Studien”, lecz przede wszystkim popularyzacją filozofii myśliciela z Królewca, co wiązało się u nas z prowadzeniem prac translatorsko-edytorskich. Polska filozofia odpowiedziała też na kolejne ważne wystąpienie Vaihingera ${ }^{15}$. W 1904 roku wystąpił on z odezwą An die Freunde der kantischen Philosophie. Bericht über die

${ }^{12}$ Zob. Immanuel Kant, Krytyka czystego rozumu, przełożył z oryginału Piotr Chmielowski, pod redakcją naukową Henryka Struvego z dodaniem „Wstępu” i „Objaśnień tłumacza” oraz „Skorowidzu nazwisk” i „Wyrazów naukowych” (Warszawa: Księgarnia E. Wende i Sp., Wydanie z zapomogi Kasy Pomocy dla osób pracujących na polu naukowem imienia Dra Józefa Mianowskiego, 1904). Ważna jest też dołączona i poprzedzająca sam przekład „Przedmowa Chmielowskiego”. Zob. P. Chmielowski, „Kilka słów o «Krytyce czystego rozumu»”: Immanuel Kant, Krytyka czystego rozumu, X-XLI.

${ }^{13}$ Zob. Emmanuel Kant, Prolegomena do wszelkiej przyszłej metafizyki, która będzie mogła wystapić jako nauka, z oryginału przełożył oraz wstępem i przypisami opatrzył Benedykt Bornstein, (Biblioteka Filozoficzna Klasyków, pod redakcją Warszawskiego Instytutu Filozoficznego, Warszawa: Skład Główny w Księgarni Gebethnera i Wolffa, Wydanie z zapomogi Kasy Pomocy dla osób pracujących na polu naukowym imienia Dra Józefa Mianowskiego, 1918).

${ }^{14} \mathrm{~W}$ swoich Dziennikach Twardowski wspomina o pomyśle ponownego wydania Uzasadnienia metafizyki moralności. Zob. Kazimierz Twardowski, Dzienniki, cz. II 1928-1936, do druku przygotował, wprowadzeniem i przypisami opatrzył Ryszard Jadczak (Warszawa-Toruń: Adam Marszałek), 2002, 150.

${ }^{15}$ Hans Vaihinger, „Das Kantjubiläum im Jahre 1904”: Kant-Studien 10 (1905): 105-155. 
Begründung einer "Kantgesellschaft” und die Errichtung einer "Kantstiftung” zum hundertjährigen Todestag des Philosophen ${ }^{16}$. Zachęcał w niej do podjęcia badań nad recepcją filozofii Kanta w świecie i prosił o organizowanie oddziałów światowych Towarzystwa Kantowskiego. U nas odezwę Vaihingera przetłumaczono i opublikowano w „Przeglądzie Filozoficznym”: Jubileusz Kanta (Odezwa H. Vaihingera $w$ sprawie Towarzystwa Kantowskiego $i$ wspierania Kantstudien $)^{17}$. Wspomniał o niej również Struve w swojej pracy Immanuel Kant a dziejowa doniosłość jego krytycyzmu ${ }^{18}$.

Wszystkie te działania doprowadziły polskich filozofów do podjęcia starań o to, by obchody rocznicy urodzin Kanta w 1904 roku uczcić założeniem we Lwowie Polskiego Towarzystwa Filozoficznego. Animatorem tych starań był Twardowski, a wspomagali go Struve i Weryho. Kant znalazł swoje poczesne miejsce. Elementy jego filozofii zostały szeroko wykorzystane w przytoczonej przez nas „Przemowie” Twardowskiego, jak i w odczycie inauguracyjnym Chmielowskiego ${ }^{19}$.

Początek działań polskich filozofów, zwłaszcza Twardowskiego, Struvego i Weryhy, na rzecz popularyzacji Kantowskiej filozofii był imponujący. Można było mieć nadzieję na wyraźny postęp w recepcji filozofii Kanta w Polsce. Struve, jako redaktor wspieranej przez „Kasę Mianowskiego” „Biblioteki Filozoficznej”, wytrwale zabiegał o dotacje na publikację Kantowskich dzieł w języku polskim. Na tym polu wspierali go Weryho i Twardowski. Ten ostatni swoją troskę i starania o poprawność oraz rzetelność polskich przekładów prac światowych wyraził m.in. w 1913 roku w prowadzonym przez siebie „Ruchu Filozoficznym”. Opublikował tam odezwę w Sprawie polskich przekładów dzieł filozoficznych. Pisał wówczas o polskich przekładach dzieł Kanta $\mathrm{z}$ wielką powagą:

\footnotetext{
${ }^{16}$ Hans Vaihinger, „An die Freunde der kantischen Philosophie. Bericht über die Begründung einer «Kantgesellschaft» und die Errichtung einer «Kantstiftung» zum hundertjährigen Todestag des Philosophen", Kant-Studien 9 (1904): 344-350.

${ }^{17}$ Hans Vaihinger, „Jubileusz Kanta (Odezwa H. Vaihingera w sprawie Towarzystwa Kantowskiego i wspierania Kantstudien)", Przegląd Filozoficzny 7 (1904), 1: 108-109.

${ }^{18}$ Zob. Henryk Struve, Immanuel Kant oraz dziejowa doniosłość jego krytycyzmu (Warszawa: Biblioteka Warszawska, T. 3, 1904), 13-15.

${ }^{19}$ Piotr Chmielowski, „Kant w Polsce”, Przegląd Filozoficzny 7 (1904), 4: 379-394.
} 
Jak często jednak naszym przekładom filozoficznym nie tylko do takiego ideału, lecz nawet do takich starań daleko! Ile w nich germanizmów, gallicyzmów, anglicyzmów! Jak wiele w nich dowodów, że tłumacz ani pod względem językowym, ani pod względem rzeczowym oryginału nie rozumiał! A zarzutów tego rodzaju nie można niekiedy oszczędzić także takim przekładom, które pojawiają się pod bardzo poważnymi firmami! Dość przypomnieć polski przekład „Krytyki czystego rozumu” albo „Prolegomenów do wszelkiej przyszłej metafizyki, która będzie mogła wystąpić jako nauka”. A przecież jest chyba rzeczą oczywistą, że ktoś, co nie poświęcał się specjalnym studiom nad filozofią Kantowską, nie potrafi przełożyć jego dzieł na język inny, chociażby nawet sam język Kant nie sprawił mu trudności. Jakżeż bowiem można bez dokładnej znajomości i gruntownego zgłębienia filozofii Kanta poradzić sobie z jego terminologią? Jakżeż można zdać sobie sprawę z możności różnego sposobu interpretowania pewnych zdań i ustępów? Jakżeż można dokonać uzasadnionego wyboru między tymi różnymi interpretacjami albo przełożyć oryginał tak, aby ta możność różnego sposobu interpretowania pozostała także w przekładzie? A to, co jest postulatem niewątpliwym i słusznym, gdy chodzi o przekład dzieł Kanta, nie przestaje być słusznym, gdy chodzi o autora „łatwiejszego”. Kompetencja fachowa obok kwalifikacji językowych jest zawsze niezbędna; w przeciwnym razie powstają przekłady trudniej niekiedy zrozumiałe od oryginału, niekiedy też wprost wypaczające jego myśli ${ }^{20}$.

Szczególnie ważne było $\mathrm{w}$ tym momencie dla Twardowskiego ponowne tłumaczenie i wydanie Prolegomenów. Warto jeszcze raz podkreślić, że to właśnie Twardowski, jako pierwszy w naszej filozofii, odważnie wprowadził i czytał to dzieło Kanta podczas swoich zajęć. Czynił to przez niemal cały okres swojej pracy dydaktycznej. Jeszcze w notatce z 6 lutego 1927 roku zapisał:

Przed południem na uniwerku. O godzinie wpół do pierwszej zebrało się w sali posiedzeń Seminarium filozoficznego 13 uczestników ćwiczeń filozoficznych, by ułożyć co do urządzenia wspólnej lektury dwa razy na tydzień. Postanowiliśmy czytać Kanta „Prolegomena”. Na razie we wtorki od piątej do szóstej i we środy od jedenastej do dwunastej ${ }^{21}$.

${ }^{20}$ Zob. Kazimierz Twardowski, „W sprawie polskich przekładów dzieł filozoficznych”, Ruch Filozoficzny III (1913) 5: 105-106.

${ }^{21}$ Zob. Twardowski, Dzienniki, cz. I, 1915-1927, 293. 
Twardowski był animatorem obu naszych przekładów Kantowskich Prolegomenów. Przyczynił się nie tylko do ich powstania, lecz także do rozpoczęcia dyskusji wokół nich. Zachęcał do dzielenia się refleksjami na ich temat na łamach „Przeglądu Filozoficznego” i „Ruchu Filozoficznego”.

\section{Dzieje polskich przekładów Kantowskich Prolegomenów. Znaczenie działań Kazimierza Twardowskiego}

Filozofia Kanta na przełomie XIX i XX wieku, jak już wspomnieliśmy, cieszyła się szczególnym uznaniem i zainteresowaniem w polskiej myśli odradzającej się po latach zaborów. Jego dzieła trafiały na pulpit zarówno tłumaczy, jak i filozofów. Przez Twardowskiego w szczególny sposób zostały wyróżnione Prolegomena. To dzieło Kanta stało się za jego namową przedmiotem dwóch przekładów i dwóch ważnych polemik. Przebiegały one kolejno na przełomie 1907 i 1908 roku na łamach „Przeglądu Filozoficznego” oraz 1921 i 1922 roku na łamach „Ruchu Filozoficznego”. Pierwsza z nich dotyczyła przekładu z 1901 roku autorstwa Grzymały-Piątkowskiego ${ }^{22}$. Naprzeciw siebie stanęło dwóch wybitnych myślicieli, znawców filozofii Kanta i obrońców rzetelnego oraz krytycznego filozofowania, a mianowicie Struve i Hersz $\mathrm{Bad}^{23}$. Spór ten wywołał Twardowski. Dostrzegł bowiem w przekładzie Grzymały-Piątkowskiego wiele błędów. Zachęcił swojego lwowskiego ucznia Hersza Bada do tego, aby podjął na łamach „Przeglądu Filozoficznego”

${ }^{22}$ Immanuel Kant, Prolegomena do wszelkiej przyszłej metafizyki, która będzie mogła wystąpić jako nauka, $Z$ dodaniem Słownika terminów filozoficznych, użytych $w$ tym przekładzie, przełożył z oryginału Romuald Piątkowski, pod redakcją Henryka Struvego (Warszawa: Wydanie z zapomogi Kasy pomocy dla osób, pracujących na polu naukowym imienia D-ra Józefa Mianowskiego, Skład Główny w Księgarni E. Wende i Sp., 1901).

${ }^{23}$ Zob. następujące teksty w sprawie tej polemiki: Hersz Bad, „W sprawie polskiego przekładu dzieła Kanta pt. «Prolegomena do wszelkiej przyszłej metafizyki»", przekład Romuald Piątkowski, Warszawa 1901: Przegląd Filozoficzny 10 (1907), 1: 74-94; Henryk Struve, „Odpowiedź na zarzuty pana H. Bada co do polskiego przekładu Prolegomenów Kanta oraz wiadomość o przekładach francuskich i angielskich”: Przeglad Filozoficzny 10 (1907), 2: 2, 218 -227, oraz dalsza polemika w Przeglądzie Filozoficznym 11 (1908), 1/2: 35-46 [uwagi H. Bada i uwagi H. Struvego]; Hersz Bad, „Jeszcze w sprawie polskiego przekładu Prolegomenów Kanta”, Przeglad Filozoficzny 11 (1908), 1: 35-46. 
polemikę na ten temat $\mathrm{z}$ wydawcą przekładu. W ten sposób doszło do starcia dwóch godnych siebie adwersarzy, co stało się wyśmienitym pretekstem do popularyzacji filozofii Kanta. Twardowski osobiście czuwał nad przebiegiem sporu. Zachęcał polemistów do odważnego prezentowania własnych odmiennych punktów widzenia. Otwartość umysłu nie pozwalała mu jednak stanąć po żadnej ze stron sporu. Spotkanie tak wyśmienitych myślicieli jak Henryk Struve i Hersz Bad traktował raczej jako okazję do szerszej prezentacji filozofii Kanta. Wiedział jednak, że istnieje potrzeba przygotowania nowego polskiego przekładu dzieła i wyeliminowania z niego błędów, które popełnił Grzymała-Piątkowski.

Spór między Badem a Struvem, zainspirowany niewątpliwie przez Twardowskiego, znacząco wpłynął na dalsze losy polskich edycji dzieła Kanta. Krytyczna recenzja Bada, zwłaszcza bardzo skrupulatnie wymienione przez niego zarzuty językowe i merytoryczne spowodowały, że tłumaczenie Grzymały-Piątkowskiego nie doczekało się kolejnych wydań. W tym momencie Twardowski postanowił zaczekać na właściwego tłumacza, który na nowo podejmie się przekładu Prolegomenów. Przyszło mu na to oczekiwać aż siedemnaście lat. Nie był to jednak czas stracony. Między 1901 a 1918 rokiem ukazały się inne polskie wydania prac Kanta. W 1904 roku opublikowano Krytykę czystego rozumu w tłumaczeniu Chmielowskiego. W 1906 roku Wartenberg przełożył Uzasadnienie metafizyki moralności $i^{24}$. Z kolei w 1911 roku niezależnie od siebie Bornstein i Kierski dokonali przekładu Krytyki praktycznego rozumu ${ }^{25}$. Inicjatorem tych prób był Twardowski. Istotnie przyczynił się do podniesienia jakości przekładów i wzmógł zainteresowanie królewieckim myślicielem w Polsce. Bezpośrednim rezultatem jego działań był drugi przekład Kantowskich Prolegomenów. Na jego autora Twardowski wy-

\footnotetext{
${ }^{24}$ Immanuel Kant, Uzasadnienie metafizyki moralności, tłum. Mścisław Wartenberg (Lwów: Polskie Towarzystwo Filozoficzne, 1906).

${ }^{25}$ Immanuel Kant, Krytyka praktycznego rozumu, z oryginału przełożył Feliks Kierski, wstępem poprzedził Mścisław Wartenberg (Lwów: Polskie Towarzystwo Filozoficzne, Skład Główny w Ksiegarni H. Altenberga, 1911); Immanuel Kant, Krytyka praktycznego rozumu, z oryginału przełożył oraz wstępem i przypisami zaopatrzył Benedykt Bornstein, pod redakcyą Henryka Goldberga (Warszawa: Skład Główny w księgarni H. Wende i Ska (T. Hiż i A. Turkuł), 1911).
} 
brał Bornsteina ${ }^{26}$. Obudził również ponowne zainteresowanie Hersza Bada. Jego recenzja, która ukazała się w „Ruchu Filozoficznym”, różniła się jednak znacząco od tej dotyczącej tłumaczenia Piątkowskiego ${ }^{27}$. Docenił on kunszt oraz wiedzę filozoficzną tłumacza. Bad, świadom tego, że ma do czynienia nie tylko z samym tłumaczem, lecz z osobowością filozoficzną namaszczoną przez Twardowskiego, nie odważył się zakwestionować umiejętności translatorskich Borsteina. Jedyne, na co mógł sobie pozwolić w swojej recenzji, to ukazanie kilku drobnych usterek.

Wysiłki Bornsteina ostatecznie docenił też Twardowski. Dumny był zwłaszcza z cennej „Przedmowy” tłumacza, która powstała przy jego wyraźnym wsparciu. Borstein za sprawą Twardowskiego poruszył w niej zagadnienia do tej pory niepodejmowane w polskiej literaturze filozoficznej. Chodziło przede wszystkim o relacje między Krytyka czystego rozumu a Prolegomenami, którymi Twardowski zajmował się we Lwowie podczas swoich zajęć seminaryjnych. Ponadto Bornstein zaprezentował, dzięki podpowiedziom Twardowskiego, ważny spór Erdmanna z Arnoldtem dotyczący genezy i historii powstania Prolegomenów ${ }^{28}$. Wskazał też na inny istotny aspekt, jakim okazał się problem metody zastosowanej w Krytyce czystego rozumu i Prolegomenach. W tym pierwszym dziele, co podkreślił Bornstein, Kant zastosował metodę syntetyczną. Z kolei wykład w drugim dziele przeprowadzony był analitycznie. To wskazanie pochodziło także od Twardowskiego. Wresz-

\footnotetext{
${ }^{26}$ Emmanuel Kant, Prolegomena do wszelkiej przyszłej metafizyki, która będzie mogła wystąpić jako nauka, z oryginału przełożył oraz wstępem i przypisami opatrzył Benedykt Bornstein, (Warszawa: Biblioteka Filozoficzna Klasyków, pod redakcją Warszawskiego Instytutu Filozoficznego, Warszawa: Skład Główny w Księgarni Gebethnera i Wolffa, Wydanie z zapomogi Kasy Pomocy dla osób pracujących na polu naukowem imienia Dra Józefa Mianowskiego, 1918).

${ }^{27}$ Hersz Bad, „Recenzja Prolegomenów do wszelkiej przyszłej metafizyki, która będzie mogła wystąpić jako nauka, Z oryginału przełożył oraz wstępem i przypisami opatrzył Benedykt Bornstein”, Warszawa: Biblioteka Filozoficzna Klasyków, pod redakcją Warszawskiego Instytutu Filozoficznego, Skład Główny w Księgarni Gebethnera i Wolffa, Wydanie z zapomogi Kasy Pomocy dla osób pracujących na polu naukowym imienia Dra Józefa Mianowskiego, 1918: Ruch Filozoficzny Lwowski 6 (1921/1922), 6/7: 88b-90b.

${ }^{28}$ Benedykt Bornstein, „Kilka słów o «Prolegomenach do wszelkiej przyszłej metafizyki, która będzie mogła wystąpić jako nauka»: Wprowadzenie do Emmanuela Kanta Prolegomenów", 90a.
} 
cie Bornstein omówił w swojej „Przedmowie” hipotezę Vaihingera ${ }^{29}$ dotyczącą kolejności drukowanych w dziele ustępów. W ten sposób po raz kolejny poszedł za wskazaniem Twardowskiego i w ślad za Vorländerem, który jako pierwszy dokonał edycji Prolegomenów zgodnie z sugestiami Vaihingera, zamieniając kolejność pięciu fragmentów następujących po pierwszym ustępie w paragrafie czwartym.

Bornstein wszystkie podpowiedzi przy swoim tłumaczeniu Prolegomenów dostał niewątpliwie od Twardowskiego. To on wydatnie przyczynił się do ostatecznego kształtu drugiego z kolei polskiego przekładu Prolegomenów. Stał się w ten sposób animatorem obu rodzimych wydań i największym polskim popularyzatorem badań nad filozofią Kanta podczas zaborów i w wolnej międzywojennej Polsce. Wysoka jakość tłumaczenia Bornsteina uzyskała dzięki Twardowskiemu należytą rekomendację. Po II wojnie światowej dzieło to doczekało się dwóch reedycji. Pierwsza miała miejsce w 1960 roku w opracowaniu Janiny Suchorzewskiej, druga zaś w 2012 roku w opracowaniu Mirosława Żelaznego. W obu pominięta została „Przedmowa” Bornsteina. Zrezygnowano z przedstawienia genezy Kantowskich Prolegomenów.

\section{Bibliografia}

Bad Hersch. 1905. „Sprawozdanie H. Bada Dr. Sitzlera Zur Blattversetzun in Kant Prolegomena (Przyczynek do sprawy o pomieszaniu kartek w Prolegomenach Kanta)". Przegląd Filozoficzny (8) 3: 281.

Bad Hersz. 1907. „W sprawie polskiego przekładu dzieła Kanta pt. «Prolegomena do wszelkiej przyszłej metafizyki», przekład Romuald Piątkowski. Warszawa 1901”. Przeglad Filozoficzny (10) 1: 74-94.

\footnotetext{
${ }^{29}$ Hans Vaihinger, „Eine Blattversetzung in Kants Prolegomena”, Philosophische Monatshefte XV (1878): 321-332. Pisał o tym Benedykt Bornstein, „Kilka słów o «Prolegomenach do wszelkiej przyszłej metafizyki, która będzie mogła wystąpić jako nauka»": Emanuel Kant, Prolegomena do wszelkiej przyszłej metafizyki, która będzie mogła wystapić jako nauka, tłum. B. Bornstein, XV-XVIII. W polskiej literaturze filozoficznej na temat hipotezy Vaihingera pisał w 1905 roku nie kto inny jak właśnie Hersz Bad. Zob. „Sprawozdanie H. Bada Dr. Sitzlera Zur Blattversetzun in Kant Prolegomena (Przyczynek do sprawy o pomieszaniu kartek w Prolegomenach Kanta)", Przeglad Filozoficzny 8 (1905), 3: 281.
} 
Bad Hersz. 1908. „Jeszcze w sprawie polskiego przekładu Prolegomenów Kanta”. Przegląd Filozoficzny (11) 1: 35-46.

Bad Hersz. 1921/1922. „Recenzja Prolegomenów do wszelkiej przyszłej metafizyki, która będzie mogła wystąpić jako nauka, Z oryginału przełożył oraz wstępem i przypisami opatrzył Benedykt Bornstein”. Warszawa: Biblioteka Filozoficzna Klasyków, pod redakcją Warszawskiego Instytutu Filozoficznego, Skład Główny w Księgarni Gebethnera i Wolffa. Wydanie z zapomogi Kasy Pomocy dla osób pracujących na polu naukowym imienia Dra Józefa Mianowskiego, 1918. Ruch Filozoficzny Lwowski (6) 6/7: 88b-90b.

Brożek Andrzej. 1981. „Piątkowski Romuald Grzymała”. W: Polski słownik biograficzny. T. 26, z. 1: 18-19. Kraków: Zakład Narodowy im. Ossolińskich - Wydawnictwo Polskiej Akademii Nauk 1981.

Chmielowski Piotr. 1904. „Kant w Polsce”. Przegląd Filozoficzny (7) 4: 379-394.

Jadczak Ryszard. 1991. Kazimierz Twardowski. Nota bibliograficzna, „Spis wykładów i seminariów Kazimierza Twardowskiego w Uniwersytecie Lwowskim”. Toruń: nakł. aut.

Kant Emmanuel. 1918. Prolegomena do wszelkiej przyszłej metafizyki, która będzie mogła wystąpić jako nauka, z oryginału przełożył oraz wstępem i przypisami opatrzył Benedykt Bornstein. Biblioteka Filozoficzna Klasyków, pod redakcją Warszawskiego Instytutu Filozoficznego. Warszawa: Skład Główny w Księgarni Gebethnera i Wolffa, Wydanie z zapomogi Kasy Pomocy dla osób pracujących na polu naukowym imienia Dra Józefa Mianowskiego.

Kant Immanuel. 1864. Krytyka czystego rozumu, fragmenty w przekładzie polskim tłum. Leon Grabowski, Ekonomia polityczna, (Warszawa), „Oddz. 1, Teoria ekonomii politycznej", 25-48.

Kant Immanuel. 1901. Prolegomena do wszelkiej przyszłej metafizyki, która będzie mogła wystąić jako nauka, $Z$ dodaniem Słownika terminów filozoficznych, użytych $w$ tym przekładzie, przełożył z oryginału Romuald Piątkowski, pod redakcją Henryka Struvego. Warszawa: Wydanie z zapomogi Kasy pomocy dla osób, pracujących na polu naukowym imienia D-ra Józefa Mianowskiego, Skład Główny w Księgarni E. Wende i Sp.

Kant Immanuel. 1904. Krytyka czystego rozumu, przełożył z oryginału Piotr Chmielowski, pod redakcją naukową Henryka Struvego z dodaniem „Wstępu” i „Objaśnień tłumacza” oraz „Skorowidzu nazwisk” i „Wyrazów naukowych”. Warszawa: Księgarnia E. Wende i Sp., Wydanie z zapomogi Kasy Pomocy dla osób pracujących na polu naukowem imienia Dra Józefa Mianowskiego.

Kant Immanuel. 1906. Uzasadnienie metafizyki moralności, tłum. Mścisław Wartenberg. Lwów: Polskie Towarzystwo Filozoficzne.

Kant Immanuel. 1911. Krytyka praktycznego rozumu, z oryginału przełożył Feliks Kierski, wstępem poprzedził Mścisław Wartenberg. Lwów: Polskie Towarzystwo Filozoficzne, Skład Główny w Ksiegarni H. Altenberga. 
Kant Immanuel. 1911. Krytyka praktycznego rozumu, z oryginału przełożył oraz wstępem i przypisami zaopatrzył Benedykt Bornstein, pod redakcją Henryka Goldberga. Warszawa: Skład Główny w księgarni H. Wende i Ska (T. Hiż i A. Turkuł).

Kant Immanuel. 1997. Projekt wieczystego pokoju. Rozwaga filozoficzna, tłum. Szymon Bielski. Królewiec.

Kazimierz Twardowski. 1913. „W sprawie polskich przekładów dzieł filozoficznych”. Ruch Filozoficzny (3) 5: 105-106.

Kuliniak Radosław, Dorota Leszczyna. 2015. Spory wokół polskich przekładów dzieł Immanuela Kanta $z$ lat 1795-1918. Wrocław: Atut.

Leszczyna Dorota. 2011. José Ortega y Gasset. Dziedzictwo Kanta i neokantyzmu marburskiego. Wrocław: Wydawnictwo: Arboretum.

Ortega y Gasset José. 2004-2010. Prólogo para alemanes. W: Obras completas, t. I-X, Madrid Fundación José Ortega y Gasset/Centro de Estudios Orteguianos.

Struve Henryk, 1904. Immanuel Kant oraz dziejowa doniostość jego krytycyzmu. Warszawa: Biblioteka Warszawska, t. 3.

Struve Henryk. 1898. Wstęp krytycznym do filozofii. Warszawa, wyd. II poprawione.

Struve Henryk. 1904. „Od Redaktora »Biblioteki filozoficznej« (Napisana w Eltham pod Londynem w lutym 1904 r.)": w: Immanuel Kant, Krytyka czystego rozumu, przełożył z oryginału Piotr Chmielowski, pod redakcją naukową Henryka Struvego z dodaniem „Wstępu” i „Objaśnień tłumacza” oraz „Skorowidzu nazwisk” i „Wyrazów naukowych”. Warszawa: Księgarnia E. Wende i Sp., Wydanie z zapomogi Kasy Pomocy dla osób pracujących na polu naukowym imienia dra Józefa Mianowskiego.

Struve Henryk. 1904. Immanuel Kant oraz dziejowa doniosłość jego krytycyzmu. Warszawa: Biblioteka Warszawska.

Struve Henryk. 1907. „Odpowiedź na zarzuty pana H. Bada co do polskiego przekładu Prolegomenów Kanta oraz wiadomość o przekładach francuskich i angielskich". Przeglad Filozoficzny (10) 2: 218-227.

Twardowski Kazimierz, „Kanta Prolegomena w streszczeniu”, mps 17 x 21 cm., k. 14, po k. 16, k. A-H. luźne. 1. Tekst, k. 1-6. 2; „Anmerkung”, k. A-H. Nr spisu inw., P. 18,7, Archiwum Połączonych Bibliotek WFiS UW, IFiS PAN i PTF, Archiwum Kazimierza Twardowskiego, w Warszawie.

Twardowski Kazimierz. 1904. „Przemówienie inauguracyjne z okazji otwarcia Polskiego Towarzystwa Filozoficznego we Lwowie". Przegląd Filozoficzny Warszawski (7) 2: 241-243.

Twardowski Kazimierz. 2002. Dzienniki, cz. II 1928-1936, do druku przygotował, wprowadzeniem i przypisami opatrzył Ryszard Jadczak. Warszawa-Toruń: Adam Marszałek.

„Wykaz wykładów odbywać się mających w C. K. Uniwersytet imienia Cesarza Franciszka I. we Lwowie. Skład Uniwersytetu i program wykładów z lat 1876-1939”. 
Vaihinger Hans. 1878. „Eine Blattversetzung in Kants Prolegomena”. Philosophische Monatshefte XV: 321-332.

Vaihinger Hans. 1904. „An die Freunde der kantischen Philosophie. Bericht über die Begründung einer «Kantgesellschaft» und die Errichtung einer «Kantstiftung» zum hundertjährigen Todestag des Philosophen“. Kant-Studien 9: 344-350.

Vaihinger Hans. 1904. „Jubileusz Kanta (Odezwa H. Vaihingera w sprawie Towarzystwa Kantowskiego i wspierania Kantstudien)". Przeglad Filozoficzny (7) 1: 108-109.

Vaihinger Hans. 1905. „Das Kantjubiläum im Jahre 1904”. Kant-Studien 10: 105-155. Żelazny Mirosław. 2005, „Referat Piotra Chmielowskiego «Najdawniejsze wiadomości o E. Kancie w piśmiennictwie naszem»". Ruch Filozoficzny (LXII) 1: 58-60.

\section{Abstract \\ Did Kazimierz Twardowski deal with Immanuel Kant's philosophy?}

The aim of this research project is to present Polish reception of Immanuel Kant's philosophy in the late $19^{\text {th }}$ and early $20^{\text {th }}$ century. We particularly consider the controversy, discussions and disputes over Polish translations of the works by Kant made by Polish researchers in the years 1795-1918. We wish to prove that the translation efforts then made and the resulting polemic were equally valuable and parallel to the research and discussions in Germany. They resembled the disputes between Vaihinger and Witt, or Erdmann and Arnoldt. Polish researchers dealing with Kant's philosophy (Bornstein, Struve, Piątkowski, Chmielowski, Wartenberg, Bad) followed the paths of Vaihinger, Adickes, Erdmann and other German thinkers, popularizing and developing arrangements made by them. They followed the slogan "back to Kant" thus making the translation a priority. The first Polish translation of works by Kant was Perpetual peace project: A Philosophical Sketch in the translation by Bychowiec and Bielski (1795/1796). After these publications, already in the $19^{\text {th }}$ and $20^{\text {th }}$ centuries, other Polish translations of the works by Kant were created consecutively. The most important was A Critique of Pure Reason, the first complete translation by Chmielowski, issued in 1904. The last of the old Polish translations of the works by Kant was issued in 1918, the year in which Poland regained independence. It was Prolegomena to any Future Metaphysics That Will Be Able to Present Itself as a Science, and the translation was made by Bornstein. After that, no other Polish translation of the works by Kant appeared before the World War II outbreak. This does not mean that Kant's philosophy in interwar Poland was forgotten. It affected the way we developed philosophy, especially between two Kantian events: the 100th anniversary of Kant's death in 1904 and the 200th anniversary of Kant's birth in 1924. The assimilation of Kant's philosophy in Poland was related to proper reading of 
Kant's criticism, the reception Kant's philosophy in Lviv philosophical school, as well as the establishment of the Polish Philosophical Society in Lviv. This research project consists of four works. The first one is devoted to the controversy around the first two Polish translations of Kant's Prolegomena to any Future Metaphysics That Will Be Able to Present Itself as a Science. The discussion took place in "Warsaw Philosophical Review" and "Lviv Philosophical Movement". The second work concerns the controversy around the first Polish translation of Kant's Critique of Pure Reason. The most important voices include Struve's correspondence with Chmielowski, Struve's review and voice in this matter published in "Warsaw Courier", "Appendix to the Lviv Courier" and "Warsaw Philosophical Review", and Mahrburg's review in the "Warsaw Book". In the third one, we describe the pre-war Polish disputes concerning Kant's Critique of Practical Reason. It concerns the translation by Kierski (1911), and Bornstein (1911). The discussions in "Lviv Philosophical Movement", "Warsaw Book" and "Warsaw Philosophical Review" involved Bad, Żółtowski and Zieleńczyk. The fourth work contains a description of minor, but equally important disputes around other Polish translations of Kant's works. We also consider Polish translations of Dreams of a Spirit-Seer, illustrated by Metaphysics and Metaphysics of Morals Justification.

Keywords: Kant; Prolegomena; Twardowski; Struve; Weryho; Polish philosophy; criticism of neo-Kantianism, criticism, neo-Kantianism; Bornstein; Grzymała-Piątkowski; Hersz Bad.

\section{Streszczenie}

\section{Czy Kazimierz Twardowski zajmował się filozofią Immanuela Kanta?}

Przygotowując kilka lat temu wraz z Dorotą Leszczyną pracę poświęconą dawnym polskim przekładom Kantowskich Prolegomenów do wszelkiej przyszłej metafizyki, która będzie mogła wystąić jako nauka, nie rozwinęliśmy jednego ważnego wątku (szerzej o tej polemice piszą: Radosław Kuliniak i Dorota Leszczyna, Spory wokót polskich przekładów dzieł Immanuela Kanta z lat 1795-1918, „Cz. I. Polemiki wokół dawnych polskich przekładów Kantowskich »Prolegomenów do wszelkiej przyszłej metafizyki, która będzie mogła wystąpić jako nauka«, (Wrocław: Atut, 2015), 221. Książka zawiera wybór tekstów, dotyczący tej polemiki. Niniejsze refleksje są uzupełnieniem wskazanych rozważań. W niniejszym artykule wspieramy się na wcześniej uzyskanych wynikach badań. W wielu jego miejscach powtarzamy bez większych zmian uczynione już ustalenia). Chodziło o udział i rolę, jaką odegrał 
Kazimierz Twardowski w polskich pracach translatorskich nad Kantowskim Prolegomenami i innymi jego pracami. Działania Twardowskiego popularyzujące filozofię Kanta w naszym obszarze filozoficznym w okresie pod zaborami, a później $\mathrm{w}$ wolnej Polsce są tematem na osobną pracę. Niniejsze rozważania stanowią jedynie uzupełnienie dokonanych już przez nas ustaleń. Wraz z niniejszym artykułem prezentujemy szczęśliwie zachowane $\mathrm{w}$ archiwaliach Streszczenie Kazimierza Twardowskiego Kanta „Prolegomenów”, uczynione przez niego na użytek prowadzonych we Lwowie zajęć dydaktycznych. Tekst ten przepisała z maszynopisu i przygotowała do druku Anna Kaszmiruk. Streszczenie to potwierdza, że Twardowski nie tylko interesował się filozofią Kanta, lecz stała się ona ważnym elementem jego działalności dydaktycznej i naukowej. Nie było wówczas w Polsce bardziej zaangażowanego w jej popularyzację animatora.

Słowa kluczowe: Kant; Prolegomena; Twardowski; Struve; Weryho; filozofia polska; krytycyzm; neokantyzm; Bornstein; Grzymała-Piątkowski; Hersz Bad. 